\title{
Perbandingan Reaksi Zat Besi Terhadap Teh Hitam dan Teh Hijau Secara In Vitro dengan Menggunakan Spektrofotometer Uv-Vis
}

\author{
Husnil Wardiyah, Yustini Alioes, Dian Pertiwi
}

\begin{abstract}
Abstrak
Salah satu permasalahan gizi yang dihadapi Indonesia adalah anemia defisiensi besi. Defesiensi besi ini dapat disebabkan oleh asupan dan serapan yang tidak adekuat, seperti kebiasaan mengonsumsi zat yang dapat menghambat penyerapan zat besi seperti minum teh pada saat makan. Hambatan penyerapan ini disebabkan oleh polifenol yang terkandung di dalam teh, terutama tanin. Penelitian ini dilakukan pada teh hitam dan teh hijau yang banyak dikonsumsi masyarakat. Larutan teh hitam dan teh hijau dijadikan sebagai kontrol, kemudian diberikan perlakuan dengan meneteskan $\mathrm{FeCl} 3$ 1\% sebanyak lima tetes. Larutan tersebut dibaca besar absorbannya dengan spektrofotometer UV-Vis. Prosedur ini dilakukan dengan pengulangan sebanyak lima kali. Data hasil penelitian diolah dengan menggunakan independent sample t test untuk melihat perbedaan rata-rata pada dua kelompok sampel tersebut. Dari hasil penelitian didapatkan rata-rata besar absorban teh hitam kontrol 0,539 dan setelah diteteskan zat besi 0,30640 . Absorban teh hijau kontrol 0,961 dan setelah diteteskan zat besi 0,65020. Hal ini berarti bahwa terjadi penurunan konsentrasi larutan tersebut. Penurunan absorban pada kontrol teh hitam dengan perlakuan adalah $43,15 \%$, sedangkan pada teh hijau adalah $32,34 \%$. Berdasarkan uji statistik, disimpulkan bahwa terdapat perbedaan bermakna antara absorbansi teh hitam dan teh hijau.
\end{abstract}

Kata kunci: Teh hitam, teh hijau, zat besi, absorban.

\begin{abstract}
One of the nutritional problems faced by Indonesia is iron deficiency anemia. It is caused by inadequate intake and absorption. One of the causes of this inadequate absorption is eating habit to consume substances that can inhibit iron absorption like drinking tea while eating. This is caused by tea polyphenol compounds, especially tannins. Black tea and green tea were observed in this research since these are widely consumed by public. Solution of black tea and green tea were used as control and they were treated by giving five drops of $1 \% \mathrm{FeCl} 3$. Absorbance of those solutions was read by using spectrophotometer UV-Vis. This procedure was done with five times repetition. The result of this research was processed by using independent sample t test to discern mean of two groups samples. The result showed that the absorbance mean of black tea control is 0.539 and the absorbance mean of black tea that has dripped by iron is 0.30640 . As for the green tea control absorbance is 0.961 and absorbance mean after iron sheds is 0.65020 . It means that there is a dilution and reduction of solution concentration. Based on these figures, it was concluded that the concentration of black tea with iron sheds is smaller than the concentration of green tea with iron sheds. Nevertheless, there is a greater reduction in black tea compare with green tea in the absorbance reduction. Absorbance reduction from black tea control group to treatment group is $43.15 \%$, while absorbance reduction from green tea control group to treatment group is $32.34 \%$. Based on statistical tests, it was concluded that there is a significant difference between the absorbance of black tea and green tea.
\end{abstract}

Keywords: Black tea, green tea, iron, absorbance.

Affiliasi penulis : Fakultas Kedokteran Universitas Andalas, Korespondensi : Husnil Wardiyah, email husnilwardiyah@yahoo.com, Telp: 085263449903

\section{PENDAHULUAN}

Indonesia sampai saat ini masih dihadapkan dengan permasalahan gizi. Permasalahan gizi yang dihadapi saat ini adalah masalah gizi ganda, yaitu gizi kurang dan gizi lebih. Akan tetapi, persentasi masalah gizi kurang masih lebih besar daripada gizi lebih. Hasil riset kesehatan dasar tahun 2010 menunjukkan angka prevalensi gizi kurang pada balita di Indonesia masih sebesar 17,9\%. Angka ini masih di atas dari targetan MDGs 2015, yaitu sebesar 15,5\%. Beberapa permasalahan gizi kurang yang dihadapi Indonesia di antaranya adalah kekurangan vitamin A pada balita, gangguan akibat kekurangan iodium, dan anemia gizi pada anak umur 2-5 tahun.
Anemia gizi, khususnya anemia defisiensi besi tidak hanya dihadapi oleh Indonesia, tetapi merupakan masalah gizi yang paling sering ditemukan di dunia dan menjadi masalah kesehatan masyarakat yang bersifat epidemik. Diperkirakan $25 \%$ dari jumlah populasi dunia atau sekitar 2 miliar orang di dunia menderita anemia defisiensi besi. Anemia defisiensi besi lebih cenderung terjadi di negara berkembang. Di Indonesia, masalah anemia defisiensi besi merupakan salah satu masalah gizi yang utama. ${ }^{2-4}$

Salah satu penyebab terjadinya anemia defisiensi besi tersebut adalah asupan dan serapan yang tidak adekuat. Makanan yang banyak mengandung zat besi adalah makanan yang berasal dari daging hewan. Akan tetapi, sebagian besar penduduk di negara berkembang belum mampu mengonsumsi makanan tersebut setiap hari. Ditambah lagi dengan kebiasaan masyarakat yang 
mengonsumsi zat yang dapat menghambat penyerapan zat besi seperti teh pada saat yang bersamaan dengan makan, sehingga penyerapan besi menjadi terhambat. Hambatan penyerapan besi ini disebabkan oleh kandungan tanin yang terdapat di dalam the. . $^{5}$

Kebiasaan minum teh juga sudah menjad budaya di beberapa negara di dunia dan merupakan minuman yang paling banyak dikonsumsi manusia di dunia selain air putih, dengan rata-rata konsumsi 120 $\mathrm{mL} /$ hari per kapita. Jenis teh yang dikonsumsi di dunia adalah $78 \%$ teh hitam, $20 \%$ teh hijau, dan $2 \%$ teh oolong. Teh hitam banyak dikonsumsi oleh penduduk Eropa, Amerika Utara, dan Afrika Utara (kecuali Moroko), sementara teh hijau banyak dikonsumsi oleh penduduk Asia, termasuk Indonesia, sedangkan teh oolong banyak dikonsumsi oleh penduduk Cina dan Taiwan.,

Teh sebenarnya memiliki banyak manfaat bagi tubuh karena mengandung polifenol yang berpotensi sebagai antioksidan yang mampu melindungi tubuh dari radikal bebas. Potensi antioksidan teh lebih kuat dibandingkan dengan antioksidan yang terdapat pada buah-buahan dan sayur-sayuran. Beberapa manfaat teh yang telah diketahui antara lain menurunkan kolesterol, menurunkan risiko osteoporosis, sebagai antivirus, penghilang bau, menjaga kesehatan gigi dan mulut, meningkatkan kondisi kognitif dan psikomotor pada orang dewasa, mencegah penggumpalan darah, mencegah penyakit jantung koroner, mencegah penyakit liver, serta mencegah pertumbuhan dan perkembangan kanker, terutama kanker lambung, esofagus, dan kulit. ${ }^{7,9,10}$

Meskipun teh diketahui memiliki banyak manfaat untuk kesehatan, tetapi teh juga diketahui dapat menghambat penyerapan zat besi jika dikonsumsi pada waktu yang salah, seperti pada saat makan atau dalam satu jam setelah makan. Penghambatan penyerapan ini terjadi karena salah satu jenis polifenol yang terkandung di dalam teh tersebut, yaitu tanin. Kebiasaan inilah yang menjadi salah satu penyebab terjadinya anemia defisiensi besi. $^{5,2,7}$

Studi literatur yang dilakukan Nelson dan Poultert mengenai dampak minum teh terhadap status besi mendapatkan bukti-bukti positif bahwa teh dapat menghambat penyerapan besi. Beberapa data yang didapatkan Nelson dan Poultert antara lain, teh hitam dapat menghambat penyerapan besi nonhem sebesar 79-94\% jika dikonsumsi bersama-sama, penyerapan besi nonhem jika dikonsumsi dengan air putih sebesar $10-13 \%$, sedangkan jika dikonsumsi bersamaan dengan teh sebanyak $200 \mathrm{~mL}$ penyerapannya hanya sebesar $2-3 \%, 150 \mathrm{~mL}$ teh hitam yang dikonsumsi dalam satu jam setelah makan akan menurunkan penyerapan besi $75-80 \%$, dan teh hitam menghambat penyerapan besi hampir dua kali lipat daripada teh hijau.

Berdasarkan semua uraian di atas, maka perlu dilakukan penelitian untuk mengetahui bagaimana pengaruh teh terhadap zat besi. Percobaan akan dilakukan secara in vitro dengan menggunakan spektrofotometer UV-Vis untuk melihat besar absorban teh hitam dan teh hijau yang banyak dikonsumsi di Indonesia dan merupakan produk teh asli buatan Indonesia. Produk teh yang digunakan untuk penelitian adalah merek yang cukup populer dikonsumsi oleh masyarakat. Berdasarkan survei yang telah dilakukan pada sepuluh orang koresponden, didapatkan hasil bahwa tujuh dari sepuluh orang mengonsumsi teh hitam merek $\mathrm{S}$, sementara untuk teh hijau lima dari sepuluh orang mengonsumsi merek KD. Tujuan penelitian ini adalah untuk mengetahui perbedaan reaksi zat besi terhadap teh hitam dan teh hijau secara in vitro dengan menggunakan spektrofotometer UV-Vis.

\section{METODE \\ Jenis Penelitian}

Jenis penelitian yang dilakukan adalah penelitian eksperimental yang dilakukan pada larutan teh hitam dan teh hijau sebagai kontrol, kemudian dibuat perlakuan dengan meneteskan zat besi pada masing-masing larutan teh hitam dan teh hijau tersebut. Percobaan ini dilakukan sebanyak lima kali pengulangan.

\section{Lokasi dan Waktu Penelitian}

Penelitian dilakukuan di Laboratorium Biokimia Fakultas Kedokteran Universitas Andalas, Padang. Waktu penelitian dimulai dari bulan Mei sampai Oktober 2013.

\section{Populasi dan Sampel}

Populasi penelitian adalah teh hitam dan teh hijau yang beredar di pasaran. Sampel yang digunakan adalah teh yang paling banyak dikonsumsi oleh masyarakat berdasarkan survei yang telah dilakukan.

\section{Definisi Operasional}

1. Teh hitam adalah teh yang dibuat dengan cara dioksidasi atau fermentasi dan warna seduhannya kuning bercahaya, teh hitam yang digunakan pada penelitian ini adalah teh merek $S$ yang merupakan jenis teh hitam yang banyak dikonsumsi oleh masyarakat berdasarkan hasil survei yang telah dilakukan.

2. Teh hijau adalah teh yang dibuat tanpa proses fermentasi, tetapi dengan melakukan pemanasan, jika diseduh menghasilkan teh dengan warna terang, teh hijau yang digunakan pada penelitian ini adalah teh merek KD yang merupakan jenis teh hijau yang banyak dikonsumsi oleh masyarakat berdasarkan hasil survei yang telah dilakukan.

3. Zat besi adalah salah satu mineral mikro yang dibutuhkan tubuh untuk transportasi oksigen ke jaringan, preparat besi yang digunakan pada penelitian ini adalah $\mathrm{FeCl}_{3}$ $1 \%$ karena berdasarkan tinjauan pustaka, rata-rata besi yang diserap tubuh 1-2 mg/hari. Untuk penelitian ini, $\mathrm{FeCl}_{3}$ sebanyak $1 \mathrm{mg}$ diencerkan dengan aquades hingga mencapai konsentrasi $1 \%$.

4. Reaksi zat besi terhadap teh hitam dan teh hijau secara in vitro dilihat dengan menggunakan alat spektrofotometer UV-Vis dengan mengukur besar absoban larutan tersebut.

5. Kontrol adalah teh hitam dan teh hijau yang tidak diteteskan zat besi.

6. Perlakuan adalah teh hitam dan teh hijau yang diteteskan zat besi dengan pengulangan sebanyak lima kali. 


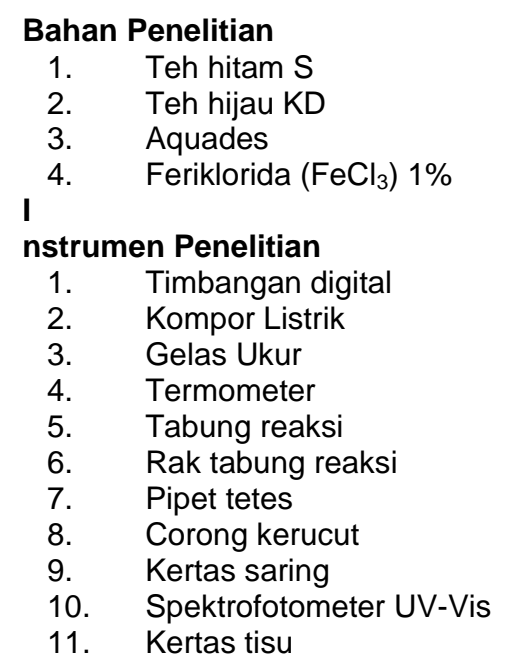

\section{Prosedur Penelitian serta Pengambilan dan} Pengumpulan Data

1. Serbuk teh hitam dan teh hijau ditimbang $1,925 \mathrm{mg}$ sebanyak lima sampel untuk masing-masing jenis teh.

2. Air dipanaskan dengan kompor listrik hingga suhu mencapai $90^{\circ} \mathrm{C}$.

3. Teh direndam dengan air sebanyak $120 \mathrm{~mL}$ selama 3 menit.

4. Sebanyak lima tetes $\mathrm{FeCl}_{3} 1 \%$ diteteskan pada sampel yang akan dibuat dengan perlakuan.

5. Teh disaring dengan kertas penyaring.

6. Teh yang telah disaring tersebut dimasukkan ke dalam tabung reaksi.

7. Teh didinginkan.

8. Sambil mendinginkan teh, alat spektrofotometer dinyalakan dan dipanaskan selama 30 menit sebelum digunakan.

9. Panjang gelombang diatur hingga panjang gelombang maksimal. Untuk penelitian ini, panjang gelombang maksimal yang digunakan adalah $580 \mathrm{~nm}$.

10. Aquades dimasukkan ke dalam kuvet dan kuvet dimasukkan ke dalam chamber, tutup chamber, tansmitan diatur hingga angka 0.

11. Sampel teh dimasukkan ke dalam kuvet dan kuvet dimasukkan ke dalam chamber, tutup chamber, dan besar transmitan dicatat.

12. Setiap akan memasukkan kuvet ke dalam chamber dan setelah selesai membaca satu sampel, kuvet dibersihkan dengan kertas tisu. Bagian permukaan luar kuvet tidak boleh dipegang.

13. Setelah melakukan pengukuran, kuvet dicuci dengan aquades, dan diletakkan secara terbalik untuk pengeringan.

14. Prosedur yang sama dilakukan untuk setiap sampel.

\section{Cara Pengolahan dan Analisis Data}

Data yang dibaca pada alat spektrofotometer adalah besar transmitan, yaitu fraksi dari radiasi yang diteruskan atau ditransimisikan oleh larutan.

Hukum Lambert menyatakan:

$$
T=\frac{I}{I o} \times 100 \%
$$

Keterangan:

$T$ : Transmisi (transmitan biasanya dinyatakan dalam $\%)$

I : Radiasi yang dipancarkan

Io : Radiasi yang datang

Untuk mendapatkan besar absorban, gunakan hukum Lambert-Beer:

Keterangan:

$$
A=\log \frac{I o}{I}=\log \frac{100}{T}=a \times b \times c
$$

$A$ : Absorban

$T$ : Transmitan

a : Konstanta yang disebut absorbsivitas

$b$ : Tebal larutan

$c$ : Konsentrasi larutan

Jika nilai $A=0$, itu artinya radiasi diteruskan $100 \%$, jika $A=1$, itu artinya radiasi diteruskan $10 \%$. Dari hukum Lambert-Beer tersebut disimpulkan bahwa konsentrasi larutan berbanding lurus dengan nilai serapan cahaya atau yang disebut juga dengan absorban. Hal ini berarti, semakin besar konsentrasi suatu larutan maka nilai absorban akan semakin besar, begitu juga sebaliknya. ${ }^{12}$

Pada spektrofotometer ini serapan maksimum dari larutan berwarna terjadi pada daerah warna yang berlawanan, misalnya warna merah akan menyerap radiasi maksimum ada warna hijau. Hal ini berarti, warna yang diserap adalah warna komplementer yang diamati. Panjang gelombang yang digunakan harus dari absorbsi maksimum larutan uji karena akan memberikan sensitivitas terbesar. Pada penelitian ini, panjang gelombang optimum yang digunakan adalah $580 \mathrm{~nm}$.

\begin{tabular}{|c|c|c|}
\hline $\begin{array}{c}\text { Panjang } \\
\text { Gelombang }(\mathrm{nm})\end{array}$ & $\begin{array}{c}\text { Warna yang } \\
\text { Diserap }\end{array}$ & $\begin{array}{c}\text { Warna yang } \\
\text { Diamati }\end{array}$ \\
\hline 410 & Violet & $\begin{array}{c}\text { Kuning hijau } \\
\text { Kuning }\end{array}$ \\
\hline 430 & Biru violet & Jingga \\
\hline 480 & Biru & Merah \\
\hline 500 & Hijau biru & Merah ungu \\
\hline 530 & Hijau & Violet \\
\hline 560 & $\begin{array}{l}\text { Kuning } \\
\text { hijau }\end{array}$ & $\begin{array}{l}\text { Biru violet } \\
\text { Biru }\end{array}$ \\
\hline 580 & Kuning & Hijau biru \\
\hline 610 & Jingga & $\mathrm{Hijau}$ \\
\hline 680 & Merah & \\
\hline 720 & Merah ungu & \\
\hline
\end{tabular}

Tabel 1. Warna Komplementer

Setelah didapatkan nilai absorban dari masing-masing sampel dengan pengulangan sebanyak lima kali, data akan diolah dengan menggunakan independent sampel $t$ test, yaitu jenis uji statistika yang bertujuan untuk membandingkan rata-rata dua grup yang tidak saling berpasangan atau tidak saling berkaitan. Tidak saling berpasangan dapat diartikan bahwa penelitian dilakukan untuk dua subjek sampel yang berbeda. Prinsip pengujian uji ini adalah melihat perbedaan rata-rata kedua kelompok data.

\section{HASIL}

Berdasarkan penelitian yang telah dilakukan di Laboratorium Biokimia Fakultas Kedokteran Universitas Andalas, Padang mengenai perbandingan reaksi zat besi terhadap teh hitam dan teh hijau secara in vitro dengan menggunakan spektrofotometer UVVis didapatkan hasil sebagai berikut. 
Tabel 2. Rata-Rata Absorban Teh Hitam dan Teh Hijau

\begin{tabular}{lcc}
\hline & \multicolumn{2}{c}{ Rata-Rata Besar Absorban } \\
\cline { 2 - 3 } & Kontrol & $\begin{array}{c}\text { Dengan } \\
\text { Perlakuan }\end{array}$ \\
\hline Teh Hitam & 0,539 & 0,30640 \\
Teh Hijau & 0,961 & 0,65020 \\
\hline
\end{tabular}

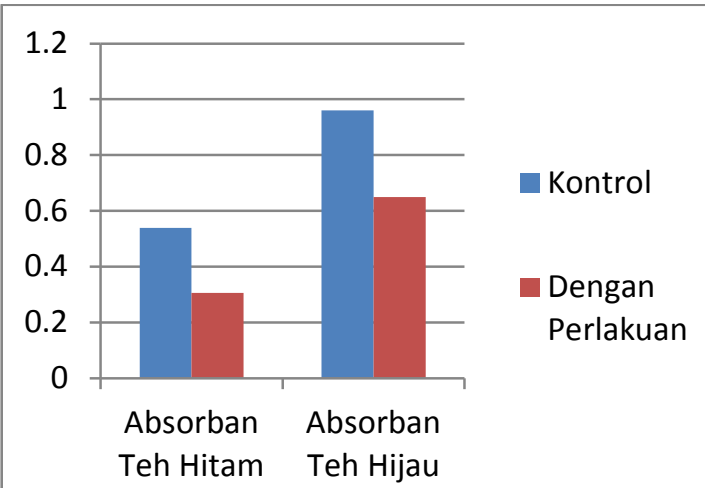

Gambar 1. Diagram Perbandingan Absorban Teh Hitam dan Teh Hijau

Tabel 3. Distribusi Rata-Rata Absorban Teh Hitam dan Teh Hijau setelah Diberikan Zat Besi

\begin{tabular}{cccccc}
\hline Jenis Teh & Mean & SD & SE & $\begin{array}{c}\mathrm{P} \\
\text { value }\end{array}$ & $\mathrm{n}$ \\
\hline Teh Hitam & 0,30640 & 0,58364 & 0,26101 & 0,000 & 5 \\
Teh Hijau & 0,65020 & 0,52870 & 0,23644 & 0,000 & 5 \\
\hline Keterangan: & & & & &
\end{tabular}

Keterangan:

SD : Standar deviasi

SE : Standar error

$\mathrm{n}$ : Jumlah sampel

Rata-rata besar absorban teh hitam adalah 0,30640 dengan standar deviasi 0,58364 , sedangkan untuk teh hijau rata-rata besar absorbannya adalah 0,65020 dengan standar deviasi 0,52870. Hasil uji statistik didapatkan nilai $p=0,000 \quad(p<0,05)$, berarti terlihat ada perbedaan yang signifikan rata-rata besar absorban antara teh hitam dan teh hijau.

\section{PEMBAHASAN}

Berdasarkan hasil penelitian didapatkan ratarata besar absorban teh hitam yang tidak diteteskan zat besi adalah sebesar 0,539 dan rata-rata absorban teh hitam yang telah diteteskan zat besi adalah sebesar 0,30640. Sedangkan untuk teh hijau yang tidak diteteskan zat besi didapatkan absorbannya sebesar 0,961 dan rata-rata absorban setelah diteteskan zat besi adalah sebesar 0,65020. Hal ini berarti bahwa terjadi pengenceran dan penurunan konsentrasi larutan tersebut, karna berdasarkan hukum Lambert-Beer, absorban berbanding lurus dengan konsentrasi larutan. Berdasarkan angka tersebut, disimpulkan bahwa konsentrasi larutan teh hitam yang diteteskan zat besi lebih kecil daripada konsentrasi teh hijau yang diteteskan zat besi. Meskipun demikian, penurunan absorban antara kontrol teh hitam dan teh hijau dengan perlakuan adalah lebih besar penurunannya pada teh hitam. Penurunan absorban pada kontrol teh hitam dengan perlakuan adalah $43,15 \%$, sedangkan pada teh hijau adalah $32,34 \% \%$.

Ketika teh direaksikan dengan zat besi, maka akan terjadi suatu reaksi pengelatan, yaitu reaksi koordinasi antara ion logam dan molekul organik yang setidaknya memiliki sepasang elektron pada setiap ujungnya, sehingga molekul organik tersebut seolaholah menyepit ion logam itu. Ikatan inilah yang menyebabkan larutan tersebut berkurang konsentrasinya. Ikatan ini terjadi karena adanya kandungan polifenol di dalam teh, terutama tanin. Secangkir teh mengandung kira-kira $30 \mathrm{mg}$ tannin. ${ }^{13}$

Hasil penelitian yang dilakukan Kaltwasser, et al. (1998) yang membandingkan penyerapan zat besi pada individu yang makan dengan minum air putih dan individu yang makan dengan minum teh hitam, didapatkan hasil bahwa penyerapan zat besi pada individu yang makan dengan minum air putih adalah sebesar $22,1 \%$, sementara individu yang makan dengan minum teh hitam sebesar 6,9\%. Dari penelitian ini disimpulkan bahwa teh hitam menurunkan penyerapan zat besi sebesar $70 \%{ }^{14}$

Hasil penelitian Thankachan, et al. (2008) pada individu yang makan dengan minum secangkir teh menurunkan penyerapan zat besi sebesar 59\%, sementara individu yang makan dengan minum dua cangkir teh penyerapan zat besi turun sebesar $67 \%$. ${ }^{15}$

Penelitian Hurrel, et al. (1999) mendapatkan hasil bahwa teh hitam merupakan inhibitor penyerapan zat besi yang paling kuat dibandingkan jenis teh lainnya karena kandungan polifenol pada teh hitam lebih besar jika dibandingkan dengan jenis teh lain. ${ }^{16}$

Jika dibandingkan antara teh hitam dan teh hijau, hambatan penyerapan zat besi oleh teh hitam lebih besar hampir dua kali lipat daripada teh hijau. Hal ini juga berkaitan dengan total fenol pada teh hitam yang lebih besar. ${ }^{17}$

\section{DAFTAR PUSTAKA}

1. Kementerian Kesehatan Republik Indonesia, 2012. Menkes: Ada Tiga Kelompok Pemasalahan Gizi di Indonesia.

2. Arisman, 2004. Gizi Dalam Daur Kehidupan: Buku Ajar Ilmu Gizi. Jakarta: EGC

3. Gibney MJ, Margetts BM, Kearney JM, Arab L, 2008. Gizi Kesehatan Masyarakat. Jakarta: EGC

4. Gilgen D, Taylor CGNM, 2001. The Effect of Weekly Iron Supplementation on Anemia and on Iron Deficiency among Female Tea Pluckers in Bangladesh. J Hum Nutr Dietet, 14; 185-190

5. Almatsier S, 2009. Prinsip Dasar Ilmu Gizi. Jakarta: PT Gramedia Pustaka Utama

6. Arisman, 2009. Gizi Dalam Daur Kehidupan: Buku Ajar IImu Gizi, Ed 2. Jakarta: EGC

7. Besral, Meilianingsih L, Sahar J, 2007. Pengaruh Minum Teh terhadap Kejadian Anemia pada Usila di Kota Bandung. Makara, Kesehatan, Vol. 11, No. 1: 38-43

8. Mukhtar H, Ahmad N. 2000. Tea Pholyphenols: Prevention of Cancer and Optimazing Health. Am J Clin Nutr 2000; 71; 1698-1702.

9. Herawati $H$, Nurawan $A, 2007$. Peningkatan Nilai Tambah Produk Teh Hijau Rakyat di Kecamatan Cikalong Wetan-Kabupaten Bandung. Jurnal Pengkajian dan Pengembagan Teknologi Pertanian Vol.10, No. 3, November 2007: 241 249.

10. Winarsi $\mathrm{H}, 2007$. Antioksidan Alami dan Radikal Bebas. Yogyakarta: Kanisius 
11. Nelson M, Poultert J, 2004. Impact of Tea Drinking on Iron Status in the UK: a review. J Hum Nutr Dietet, 17, 43-54.

12. Bintang $M, 2010$. Biokimia-Teknik Penelitian. Jakarta: Penerbit Erlangga

13. Hallberg L, Hulthen L, 2000. Prediction of Dietary Iron Absorption: an Algorithm for Calculating Absorption and Bioavailability of Dietary Iron. Am J Clin Nutr 2000;71:1147-60.

14. Kaltwasser JP, Werner E, Schalk K, Hansen C, Gottschalk R, Seidl C, 1998. Clinical Trial on the Effect of Regular Tea Drinking on Iron Accumulation in Genetic Haemochromatosis. Gut 1998;43:699-704 doi:10.1136/gut. 43.5.699.
15. Thankachan P, Walezyk T, Muthayya S, Kurpad AV, Hurrel RF, 2008. Iron Absorption in Young Indian Women: The Interaction of Iron Status with the Influence of Tea and Ascorbic Acid. Am J Clin Nutr 2008; 87; 881-6.

16. Hurrell RF, Reddy M, Cook JD, 1999. Inhibition of Non-Haem Iron Absorption in Man By Polyphenolic-Containing Beverages. British Journal of Nutrition (1999), 81, 289-295.

17. Hallberg L, Hulthen L, 2000. Prediction of Dietary Iron Absorption: an Algorithm for Calculating Absorption and Bioavailability of Dietary Iron. Am J Clin Nutr 2000;71:1147-60. 